\title{
The Parabolic Solar Water Heater
}

\author{
Shubham Thosare ${ }^{1}$, Ajay Joshi ${ }^{2}$, Amol Nimbalkar ${ }^{3}$, Nilesh Patil ${ }^{4}$, Pravin S. Patil ${ }^{5}$ \\ 1,2,3,4 UG Student, Department of Mechanical Engineering, GF'S Godavari College of Engineering Jalgaon 425003, India, \\ 1,2,3,4 UG Student, Department of Mechanical Engineering, GF'S Godavari College of Engineering Jalgaon 425003, India,
}

\begin{abstract}
A solar collector is a device that transforms solar radiation from the Sun into heat, which is then transferred to working fluid. The use of solar collectors reduces energy costs over time as they do not use fossil fuels or electricity like that as in traditional water heating. As well as in domestic settings, a large number of these collectors can be combined in an array and used to generate electricity in solar thermal power plants. There are a number of different types of solar collector designs that use the energy of the sun to heat working fluid. Each design whether a basic blackened flat panel collector or a more advanced evacuated tube collector all have their own advantages and disadvantages. Parabolic trough reflector provides a better alternative way in order to generate higher temperatures with better efficiency. The parabolic trough reflector is a solar energy collector designed to capture the sun's direct solar radiation over a large surface area and focus or "concentrate it" onto a small focal point area, increasing the solar energy received by more than a factor of two. Connecting together parabolic troughs to form collector fields requires large areas of land for the installation.
\end{abstract}

Keywords- Solar collector, Solar Radiation, Parabolic collector, Temperature.

\section{I-INTRODUCTION}

To develop a stand-alone parabolic solar heater system that can be used in rural communities to reduce hunger, dependence on wood fuel, expensive fossil fuels and other energy sources, and to alleviate poverty this type of project used on the small and biggest scale business. its better for low cost project for water heating treatment in quick and natural type of water heating without use of any electricity. In mostly rural area used this project and its used in This project researched the viability of producing high temperature industrial process heat from the sun's energy. The installation of a large scale industrial solar thermal system provides an opportunity to evaluate the technical and economic hurdles of similar systems in California.

The research was performed through the design, construction, operation, of a high temperature solar thermal system at a Frito-Lay snack food plant located in Modesto, California. In this installation, high temperature water in excess of $232^{\circ} \mathrm{C}\left(450^{\circ} \mathrm{F}\right)$ is produced by a concentrating solar field, which in turn is used to produce approximately 300 pounds per square inch (20 bar) of process steam. The solar thermal system is intended to improve plant efficiency with minimal impact on day-to-day production operations. Process steam in the plant is used for cooking, which includes heating edible oil for frying, and heating baking equipment. Steam is also converted into hot water for cleaning and sterilization processes.

Generally village level government children school for mid-day food system. 


\section{International Journal of Innovations in Engineering and Science, www.ijies.net}

\section{II - LITERATURE REVIEW}

Table 1- Literature Review

\begin{tabular}{|c|c|c|c|}
\hline TITLE & AUTHOR & $\begin{array}{l}\text { NAME OF } \\
\text { JOURNAL }\end{array}$ & YEAR \\
\hline $\begin{array}{l}\text { Steam } \\
\text { Generation by } \\
\text { using solar dish } \\
\text { collector }\end{array}$ & $\begin{array}{l}\text { S. Shinde, } \\
\text { R. Shinde, } \\
\text { A. Patil, } \\
\text { C. Desale }\end{array}$ & IRJET & $\begin{array}{l}2017, \\
\text { Vol. 04, } \\
\text { issue } 06 \\
\text { june }\end{array}$ \\
\hline $\begin{array}{l}\text { Experimental } \\
\text { Analysis of } \\
\text { Parabolic Solar } \\
\text { Dish rith } \\
\text { Copper Helical } \\
\text { coil Receiver }\end{array}$ & $\begin{array}{l}\text { V. Sakhare, } \\
\text { V. } \\
\text { Kapatkar }\end{array}$ & IJIRAE & $\begin{array}{c}2014, \\
\text { Volume } \\
1, \text { issue } 8 \\
\text { sep }\end{array}$ \\
\hline $\begin{array}{lr}\text { Design } & \text { and } \\
\text { Fabrication of } \\
\text { Parabolic Trough } \\
\text { Solar Water } \\
\text { Heater for Hot } \\
\text { Water } \\
\text { Generation }\end{array}$ & $\begin{array}{l}\text { S. Kumar } \\
\text { Singh } \\
\text { A. Kumar } \\
\text { singh S. } \\
\text { Kumar } \\
\text { Yadav }\end{array}$ & IRJET & $\begin{array}{c}2012, \\
\text { Vol } 1 \\
\text { issue } 10 \\
\text { Dec }\end{array}$ \\
\hline $\begin{array}{l}\text { An Experimental } \\
\text { study of design } \\
\text { and fabrication } \\
\text { details of } \\
\text { parabolic solar } \\
\text { dish collector for } \\
\text { water heating }\end{array}$ & $\begin{array}{l}\text { N. Kumar, } \\
\text { Anjali, } \\
\text { R. Kumar } \\
\text { Singadiya, } \\
\text { S. Shrestha }\end{array}$ & IJSET & $\begin{array}{c}2016, \\
\text { Vol 4, } \\
\text { Issue } 2 \\
\text { Aug }\end{array}$ \\
\hline
\end{tabular}

\section{III-METHODOLOGY}

For this research, a different integrated approach are used different theory are integrated by experimental study. All parties have been successful in contracting to build the project while meeting the basic requirements of this PIER project, including 54,500 square feet of solar panels with integration into existing plant steam and hot water systems. The project team recommends that current performance evaluation and tuning activities be carried out through the end of this solar season. This will allow a better understanding and optimization of performance and system utilization. Ongoing performance monitoring should continue during the lifetime of the project to assure efficiency levels are maintained. It is also recommended that similar industrial high temperature solar systems yet to be built include significant instrumentation and data collection capabilities so that the benefits of ongoing performance can be monitored and maintained.
Table 2-Reading Sample

\begin{tabular}{|c|c|c|}
\hline TIME (HRS) & $\begin{array}{c}\text { SOLAR } \\
\text { INTENCITY } \\
\left(\mathbf{W} / \mathbf{M}^{2}\right)\end{array}$ & $\begin{array}{c}\text { TEMPERATURE } \\
\left(\mathbf{0}^{\mathbf{0}} \mathrm{C}\right)\end{array}$ \\
\hline $\mathbf{8 . 0 0}$ & $\mathbf{5 0 0}$ & $\mathbf{2 4}$ \\
\hline $\mathbf{9 . 0 0}$ & $\mathbf{5 5 7}$ & $\mathbf{3 0}$ \\
\hline 10.00 & $\mathbf{5 9 5}$ & $\mathbf{4 2}$ \\
\hline 11.00 & $\mathbf{6 4 2}$ & $\mathbf{5 2}$ \\
\hline 12.00 & $\mathbf{6 9 2}$ & $\mathbf{6 1}$ \\
\hline 13.00 & $\mathbf{7 5 2}$ & $\mathbf{6 9}$ \\
\hline 14.00 & $\mathbf{7 3 2}$ & $\mathbf{6 4}$ \\
\hline 15.00 & $\mathbf{6 1 4}$ & $\mathbf{5 8}$ \\
\hline 16.00 & $\mathbf{5 1 1}$ & $\mathbf{5 3}$ \\
\hline
\end{tabular}

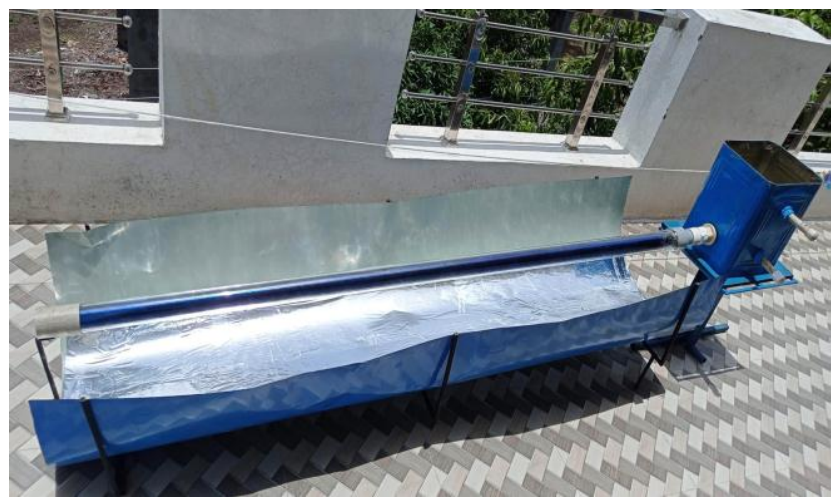

Fig. 1- Parabolic Solar Water Heater System

\section{IV-DESIGN}

The instantaneous efficiency of a PTC can be calculated from an energy balance on the receiver tube.the instantaneous efficiency is defined as the rate at which useful energy is delivered to the working fluid per unit aperature area divided by the beam solar flux at the collector aperture plane. The project team was to complete a solar concentrated solar system design which augmented the plant's existing steam systems providing at least a 20 percent reduction in natural gas demand during peak summer days. The size of the parabolic heating system is as the sheet size is about $3 \mathrm{ft}=915 \mathrm{~mm}$ approximately is about $45.8 \mathrm{~cm}$ and the focus point is about $10 \mathrm{~cm}$ during the sun temperature is at a high level the temperature approximate is about 68degress.Fabrication was done with the rule basis The instantaneous efficiency of a PTC, can be calculated from an energy balance on the receiver tube. The instantaneous efficiency is defined as the rate at which useful energy is delivered to the working fluid per unit 


\section{International Journal of Innovations in Engineering and Science, www.ijies.net}

aperture area $\left(q_{W}\right)$ divided by the beam solar flux $\left(I_{b}\right)$ at the collector aperture. It is identified as the three major design parameters which can be used to construct a three-parameter collector model for the preliminary design of PTC. The primary function of the receiver subsystem of a PTC is to absorb and transfer the concentrated energy to the fluid flowing through it. The knowledge of heat loss from the receiver is important for predicting the performance and, hence, designing. The cross-section of the receiver subsystem are three different heat exchangers exist between the components of the receiver. These are:

(1) Heat transfer from the absorber tube to the working fluid.

(2) Heat transfer between the absorber tube and the glass jacket (glassing).

(3) Heat exchange between the glass jacket and the surroundings.

Since PTC will be optimized based on instantaneous or all-day efficiency, a steady-state thermal analysis of the receiver will sufficient for design studies.

\section{V- RESULT \& DISCUSSION}

Temperature of hot water from solar water heater tested .22-70 ${ }^{0} \mathrm{C}$ from solar water heater installed at Jalgaon. (hot region).

The following formula is used for determining the efficiency of solar collector.

$$
n=\frac{\mathrm{mCp}(\text { Tout }- \text { Tin })}{\text { Gt.Ac }}
$$

$\mathrm{Ac}=$ area of collector

$\mathrm{G}_{\mathrm{t}}$ total global solar radiation intensity in $\left(\mathrm{w} / \mathrm{m}^{2}\right)$

$\mathrm{Ti}=$ the temperature of incoming water in $\left({ }^{0} \mathrm{c}\right)$

Tout $=$ the temperature water out in $\quad\left({ }^{0} \mathrm{C}\right)$

$\mathrm{Cp}=$ Specific heat of water. $\mathrm{KJ} / \mathrm{Kg}{ }^{0} \mathrm{C}$

\section{VI- CONCLUSION}

The analysis used in this paper is an alternative method of water heating from renewable energy resource with the use of parabolic solar concentrator and absorber. The heat transfer analysis performed in this paper is an effort to obtain the useful heat gain which governs the fluid temperature distribution along the tube. It has been concluded that the potential and practicality of the solar collector is dominantly influenced by many factors such as; solar collector area, absorber tube arrangements, the solar heat flux, mass flow rate and overall heat loss coefficient. The maximum efficiency obtained by using parabolic solar heater up to $68.00 \%$ and $41.04 \%$ efficiency achieved for without parabolic solar collector. Combined effect of parabolic sheet and solar glass tube absorber would provide better heat gain for solar water heating system. To work out large amount of hot water from heat energy source, a parabolic solar collector and absorber is an extremely attractive option.

\section{REFERENCES}

[1]. Shubham Shinde, Rahul Shinde, Ashish Patil , Chirag Desale(2017). Steam Generation by Using Solar Dish Collector, IRJET, Volume: 04 Issue: $06 \mid$ June -2017.

[2]. Vinayak Sakhare, V.N.Kapatkar, (2014). Experimental Analysis of Parabolic Solar Dish with Copper Helical coil Receiver, IJIRAE, Volume 1 Issue 8 September 2014

[3]. Santosh Kumar Singh, Arvind Kumar Singh, Santosh Kumar Yadav (2012). Design and Fabrication of Parabolic Trough Solar Water Heater for Hot Water Generation, Volume 01,issue 10 (2012).

[4]. Nitish Kumar, Anjali, Rajesh Kumar Singadiya, Shubhranshu Shrestha (2016) An Experimental Study of Design and Fabrication Details of Parabolic Solar Dish Collector for Water Heating, IJISET, , Volume 4 Issue 2

[5]. A.R. El Ouedernil, M. Ben Salah, F. Askri, M. Ben Nasrallah and F. Aloui "Experimental study of a parabolic solar concentrator", Revue des Energies Renouvelables Vol. 12 N³ (2009), pp 395 - 404.

[6]. Lifang Li, Steven Dubowsky "A new design approach for solar concentrating parabolic dish based on optimized flexible petals", Mechanism and Machine Theory 46(2011) pp 1536-1548.

[7]. Jasmina Radosavljević, Amelija Đorđević, "Defining of the intensity of solar radiation on horizontal and oblique surfaces on earth", Facta Universitatis Series: Working and Living Environmental Protection Vol. 2, No 1 (2001), pp. 77 - 86

[8]. K.Voropoulos,E .Mathioulakis, V. Belessiotis "A hybrid solar desalination and water heating system", Desalination, vol. 164 (2004), pp. 189-195.

[9]. Xiaowu W, Ben H. Exergy analysis of domestic-scale solar water heaters. Renew Sustain Energy Rev 2005;9(6):638-45.

[10]. Wang $X$, Wang $R, W u J$. Experimental investigation of a new-style double-tube heat exchanger for heating crude oil using solar hot water. Appl Therm Eng 2005;25(11-12):1753-63. 